\title{
CHARACTERIZATION OF ACIDOPHILIC BACTERIA RELATED TO ACIDIPHILIUM CRYPTUM FROM A COAL-MINING-IMPACTED RIVER OF SOUTH BRAZIL
}

\author{
DELABARY, G.S. ${ }^{1}$; LIMA, A.O.S. ${ }^{1}$ \& DA SILVA, M.A.C. ${ }^{1 *}$ \\ 1. Centro de Ciências Tecnológicas da Terra e do Mar, Universidade do Vale do Itajaí, Itajaí, SC, Brazil \\ *Corresponding author: marcus.silva@univali.br
}

\begin{abstract}
Delabary, G.S.; Lima, A.O.S. \& da Silva, M.A.C., 2017. Characterization of acidophilic bacteria related to Acidiphilium cryptum from a coal-mining-impacted river of South Brazil. Braz. J. Aquat. Sci. Technol. 20(2). elSSN 1983-9057. DOI: 10.14210/bjast.v20n2. Three acidophilic bacteria were isolated from water and sediment samples collected at a coal mining-impacted river, Rio Sangão, located in the city of Criciúma, Santa Catarina state, in southern Brazil. These microorganisms were isolated in acid media and were phylogenetic related to the species Acidiphilium cryptum by its $16 \mathrm{~S}$ rRNA gene sequences, although they differ from this species in the assimilation of some carbon sources. The optimum and the maximum $\mathrm{pH}$ for growth of all strains were nearly 3.0 and 5.0-6.0, respectively. Two of the strains were slightly more acidophilic, with the minimum $\mathrm{pH}$ for growth of 2.0. All strains also tolerate the four tested metals (Ni, $\mathrm{Zn}, \mathrm{Cu}$ and $\mathrm{Se}$ ) at variable concentrations, with LAMA 1486 being the most metal-resistant strain. These bacteria may belong to different ecotypes of $A$. cryptum, or even represent new species in the genus. Besides they bear characteristics that make them useful in the development of bioremediation process, for the treatment of sites contaminated with multiple toxic metals, including coal mining drainage.
\end{abstract}

Keywords: Acidiphilium, Metal resistance, Coal mining, $\mathrm{pH}$ tolerance.

\section{INTRODUCTION}

The genus Acidiphilum was originally described by Harrison (1981) as gram-negative aerobic and mesophilic bacteria that grow between $\mathrm{pH} 1.9$ and 5.9 . Since its original description, Acidiphilium was reported mainly from acid mining environments (Auld et al., 2013; Xu et al., 2013; Watling et al., 2014) where it is associated with the iron cycling, reducing ferric iron to ferrous (Küsel et al., 1999; Johnson \& Bridge, 2002; Bilgin et al., 2004). The genus was also reported to contribute to the leaching of pyrite (Hao et al., 2009), chalcopyrite (Peng et al., 2008) and marmatite (Zhang et al., 2013), and to produce poly- $\beta$-hydroxybutyrate (Xu et al., 2013).

High metal resistance is a characteristic of many acidophiles, including the heterotrophs Acidiphilium and Acidocella. Fischer et al. (2002) reported that A. cryptum was able to growth in media containing $300 \mathrm{mM}$ of aluminum sulphate $(\mathrm{pH} 3.0)$ and values as high as $700 \mathrm{mM}$ is reported for cadmium by Dopson et al. (2003). The resistance to elevated concentrations of metals is related to the presence of more efficient, or even multiple, resistance systems, in comparison to non-acidophiles, or to intrinsic tolerance, due to characteristics of the environment that they live (Dopson et al., 2014).

Acidophilic bacteria like Acidiphilium, Acidocella and the litotrophic genus Acidithiobacillus, are inhabitants of environments impacted by mining activities. In South Brazil, especially in Santa Catarina state, the contamination of aquatic resources by coal mining wastes has been considered critical. In the city of Criciúma, Alexandre \& Krebs (1995) reported low values of $\mathrm{pH}$ and dissolved oxygen, and high concentrations of iron and sulphate in the Sangão River, which received large volumes of wastewaters from coal mining and processing activities.

The main problem associated with coal mining is acid mine drainage (AMD). These are acid and metal-rich waters generated by the biotic and nonbiotic dissolution of sulfide minerals including pyrite and minerals containing zinc and copper, for instance. These minerals are oxidized in the presence of water and oxygen, producing sulfuric acid which lowers the $\mathrm{pH}$ to values below 3.0, depending on the buffering capacity of the environment (Nicomrat et al., 2006; Tan et al., 2006; Johnson et al., 2001).

Another problem associated with coal is the presence of polyaromatic hydrocarbons (PAHs) (Dore et al., 2003; Jacques et al., 2007). These organic compounds bear two or more benzene rings arranged in a linear or angular form, and are poor soluble in water, which contributes to its persistence in the environment (Fuentes et al., 2014). By its carcinogenic (Crane, 2014) and potential mutagenic activities (Meyer et al., 
2014), and its accumulation in the food chain, PAHs are considered highly dangerous to humans and other living beings.

The recovery of environments impacted by AMD may be achieved by bioremediation technologies, defined as the use of biological agents, mainly microorganisms, in the treatment of contaminated waters and soils. These technologies are environmentallyfriendly, and are considered more cost-effective and more easily implemented than other processes (Kang, 2014). Acidophilic bacteria may be employed in these remediation strategies, since they already possess the appropriate characteristics to live in acid and metal rich ecosystems. Johnson (2012), for instance, reviewed the use of Acidiphilium SJH in the remediation of mine water, by its ferric iron reducing activity, and the application of sulphate-reducing bacteria for the precipitation of toxic metals. Despite this, the acidophiles were mainly studied for their use in biohydrometallurgy (Hao et al., 2009; Johnson, 2012; Zhang et al., 2013) and much more is needed for their effective application as bioremediation agents.

Considering the problems associated with the mining activities, and the need of remediation, there is a constant interest in understand the destiny and mechanisms of removal of toxic substances present in coal wastes, including metals like zinc and copper. This knowledge may help the improvement of bioremediation techniques employing acidophilic bacteria. In this context, the present study aimed the isolation and identification of heterotrophic bacteria from samples of coal mining environments from Santa Catarina, Southern Brazil. The isolated strains were characterized regarding $\mathrm{pH}$ tolerance and metals resistance.

\section{MATERIAL AND METHODS}

\section{Sample Collection}

Water and sediment samples used in the isolation of microorganisms were collected in October 13, 2007 at the Sangão River (2948'46.73'S; $49^{\circ} 25^{\prime} 52.15^{\prime \prime}$ ), located in the city of Criciúma, Santa Catarina state, southern Brazil, and in coal waste dumps nearby. The samples were obtained from three different sampling stations, and in each both types of samples were collected in autoclave-sterilized flasks $\left(121^{\circ} \mathrm{C}\right.$, twenty minutes). Samples were kept refrigeated $\left(4^{\circ} \mathrm{C}\right)$ for less than 24 hours, until processing at the laboratory.

\section{Isolation of Microorganisms}

The microorganisms were isolated by enrichment followed by inoculation of solid media. Erlenmeyer flasks containing $80 \mathrm{ml}$ of liquid Mineral
Medium (MM) $\left(\left(\mathrm{NH}_{4}\right)_{2} \mathrm{SO}_{4}, 0.15 \mathrm{~g} / \mathrm{l} ; \mathrm{MgSO}_{4}, 0.5 \mathrm{~g} / \mathrm{l} ; \mathrm{KCl}\right.$, $0.1 \mathrm{~g} / \mathrm{l} ; \mathrm{Ca}\left(\mathrm{NO}_{3}\right)_{2}, 0.01 \mathrm{~g} / \mathrm{l} ; \mathrm{pH}=3,0$; Johnson, 1995) were inoculated with $10 \mathrm{~g}$ of sediment and $10 \mathrm{ml}$ of water from the same sample. Than naphthalene crystals were suspended over the surface of the medium to create a naphthalene-saturated atmosphere inside the flask. The inoculated media were incubated for one month at $30^{\circ} \mathrm{C}$. After each week of incubation, Petri dishes containing solid MM media were inoculated with $100 \mu$ of the enrichment liquids, and were incubated with lids side up for two weeks at $30^{\circ} \mathrm{C}$. Naphthalene crystals were put on the lids for the selection of bacteria. Colonies that developed in the solid medium were transferred to new Petri dishes several times until pure cultures were obtained. The inclusion of naphthalene in the culture media used for enrichment and isolation was intended to simulate more appropriately the types of organic compounds that may be found in coalimpacted environments, as stated in the Introduction of this article.

\section{Phenotypic Characterization of the Isolated Bacteria}

The isolated bacteria were identified by phenotypic characteristics and 16S rRNA partial sequencing (see below). Phenotypic characterization was conducted accordingly to Garrity (2004). The following morphological tests were employed: colony morphology, cell morphology and arrangement, presence of endospores, gram staining. Microscopic examination was conducted on a phase contrast microscope. The production of cytochrome oxidase was evaluated through test strips (Sigma/Aldrich) and catalase was observed by immersing one colony of the bacteria in a drop of $\mathrm{H}_{2} \mathrm{O}_{2}(3 \%)$. Anaerobic growth was evaluated incubating the microorganism in solid medium, in an anaerobic jar containing one sachet of Anaerocult (Merck), in $30^{\circ} \mathrm{C}$ for one week. The utilization of acetate, lactate, succinate $(2 \mathrm{mM})$, lactose, maltose, sorbitol and methanol $(0.1 \%)$ as the sole carbon source was evaluated in Erlenmeyer flaks of $250 \mathrm{ml}$ capacity containing $75 \mathrm{ml}$ of liquid TS medium $\left(\left(\mathrm{NH}_{4}\right)_{2} \mathrm{SO}_{4}, 2 \mathrm{~g} / \mathrm{l}\right.$; $\mathrm{MgSO}_{4} 7 \mathrm{H}_{2} \mathrm{O}, 0.5 \mathrm{~g} / \mathrm{l} ; \mathrm{KCl}, 0.1 \mathrm{~g} / \mathrm{l} ; \mathrm{KH}_{2} \mathrm{PO}_{4}, 0.5 \mathrm{~g} / \mathrm{l} ; \mathrm{pH}=$ 3,0; Kishimoto \& Tano 1987) supplemented with the specific carbon source. The inoculated media were incubated at $30^{\circ} \mathrm{C}$ for one week and optical density $(600 \mathrm{~nm})$ was measured with a spectrophotometer for growth determination.

\section{$16 S$ gene amplification, sequencing and analysis}

For the 16S rRNA sequencing, DNA was first extracted from the microorganisms cultivated for seven days at $30^{\circ} \mathrm{C}$ in $\mathrm{MM}$ supplemented with glucose $(0.1 \%)$ and yeast extract $(0.02 \%)$ (MMGY). The extraction was conducted with the Genomic DNA Extraction kit 
from Real Genomics, following the instructions of the manufacturer. The 16S rRNA gene was amplified using the primers 27F (5'-AGAGTTTGATCMTGGCTCAG-3') and 1492R (5'TACGGYTACCTTGTTACGACTT3'). The amplification was performed in a reaction volume of $35 \mu \mathrm{l}$ with $3.5 \mu \mathrm{l}$ of $10 \mathrm{X}$ concentrated buffer, $1.5 \mathrm{mM}$ $\mathrm{MgCl}_{2}, 200 \mu \mathrm{M}$ dNTP mix, $0.1 \mu \mathrm{M}$ each primer, $2.5 \mathrm{U}$ Taq polymerase and 20 to $40 \mathrm{ng}$ template DNA. The PCR conditions were initial denaturation of $2 \mathrm{~min}$ at $94^{\circ} \mathrm{C}$, followed by 35 cycles of $1 \mathrm{~min}$ at $94^{\circ} \mathrm{C}, 1.5 \mathrm{~min}$ at $55^{\circ} \mathrm{C}$ and $1 \mathrm{~min}$ at $72^{\circ} \mathrm{C}$, and a final extension at $72^{\circ} \mathrm{C}$ for $3 \mathrm{~min}$. The reaction product was visualized on an agarose gel (1\%) under UV light after ethidium bromide staining.

The amplified PCR products of bacterial gene fragments (1465 nucleotides) were purified and sequenced at MACROGEN sequencing company, Seoul, Korea using the automated sequencer ABI 3100 (Applied Biosystems) with BigDye Terminator Kit v. 3.1 (Applied Biosystems). Primers 27F (5'AGAGTTTGATCMTGGCTCAG3') and 1492R (5'TACGGYTACCTTGTTACGACTT3') were used for sequencing. The sequences obtained (1227 to 1257 nucleotides) were edited with the software Vector NTI Suite 9, and compared with the NCBI database through BLAST searches. In this comparison, sequences of type strains most closely related to the sequences of the isolates were searched. The sequences were aligned with Muscle, and the trees were constructed from the evolutionary distances by the neighbor joining method with the software Mega (Tamura et al., 2011). The 16S rRNA gene sequences obtained in this study has been deposited in the NCBI GenBank under accession numbers KP208175 to KP208177.

\section{Influence of pH on the Growth of Bacteria}

Growth of isolated bacteria was evaluated in different $\mathrm{pH}$ values (2.0, 3.0, 4.0, 5.0, 6.0, and 7.0), in 24 wells microplates containing MMGY medium. The wells were filled with $2 \mathrm{ml}$ of culture media and were inoculated with $0.1 \mathrm{ml}$ of microbial culture, prepared in MMGY (pH 3.0, $30^{\circ} \mathrm{C}$, and one week of incubation). Each organism was tested in all $\mathrm{pH}$ values, in duplicate. A non-inoculated control was included for each different $\mathrm{pH}$ value. Optical density was measured at $595 \mathrm{~nm}$ absorbance in Tecan GENios Microplate Reader at the beginning (initial value) and after the seven days of incubation (final value). The growth was evaluated from the optical density final values, from which the initial values were discounted. The average and the standard deviation were calculated and plotted. The absorbance data were analyzed with the software Statistica 7.0. The variance analysis showed statistically significant difference between the strains and the $\mathrm{pH}$ analyzed. The normal distribution and homogeneity of data were confirmed with the test of Bartlett. Then an Tukey's Test post hoc were conducted to compare the growth in different $\mathrm{pH}$ values, considering $\mathrm{p}$ levels lower than 0.05 .

\section{Tolerance to Toxic Metals}

For the determination of metal tolerance, the bacteria were cultivated in MMGY medium with different concentrations $(0.1,0.5,1.0,5.0,10.0$, and $20.0 \mathrm{mM}$ ) of the salts $\mathrm{ZnCl}_{2}, \mathrm{CuSO}_{4}, \mathrm{NiCl}_{2}{ }^{*} 6 \mathrm{H}_{2} \mathrm{O}$, and $\mathrm{Na}_{2} \mathrm{SeO}_{3}$. Each metal was tested separately. Test-tubes containing $10 \mathrm{ml}$ of MMGY medium supplemented with the various metals were inoculated with $100 \mu \mathrm{l}$ of microbial culture prepared in $\mathrm{LMM}\left(\mathrm{pH} 3.0,30^{\circ} \mathrm{C}\right.$, and one week of incubation), in duplicate for each bacteria and metal tested. A positive (culture medium without metal, inoculated with the different strains) and a negative control (non-inoculated culture medium without bacteria) were also prepared. After inoculation, the test-tubes were incubated for nineteen days at $30^{\circ} \mathrm{C}$. The optical density was measured in the spectrophotometer Femto $600 \mathrm{~S}$ at a wavelength of 600 nanometers at the beginning (initial value) and the end of incubation period (final value). The growth was obtained by the difference of the final and initial absorbance values. The average and the standard deviation were calculated, and growth was analyzed with the software Statistica 7.0. The statistical test for analysis of variance showed significant differences, normal distribution and homogeneity was confirmed with the Bartlett test. The Tukey post hoc analysis compared the growth considering the levels of $p$ less than 0.05 .

\section{RESULTS}

\section{Isolation of Bacteria and Strains Identification}

Three strains of bacteria were isolated from the mining samples, denominated LAMA 1485, LAMA 1486 and LAMA 1487. All strains were gram-negative rods with length $1.5 \mu \mathrm{m}$ and diameter less then $1.0 \mu \mathrm{m}$ and showed catalase activity (Table 1 ). They were unable of anaerobic growth and of utilizing lactose and succinate. LAMA 1487 was the only cytochrome oxidase positive strain, while LAMA 1486 was the only strain able to growth on the other carbon sources tested.

Molecular identification by $16 \mathrm{~S}$ rRNA sequencing was employed to further elucidate the taxonomy three bacterial strains cultivated (Figure 1). All strains were similar (>99\%) to Acidiphilium cryptum strains JF-5 and Lhet2. Considering the 16S rRNA gene sequence similarity range of 98.7 and $99 \%$ proposed by Stackebrandt \& Ebers (2006) the three strains might be considered as belonging to the species $A$. cryptum. 
Delabary, G.S., et al. (2017). Acidophilic bacteria from mining environments.

Table 1 - Phenotypic traits of the different $A$. cryptum strains isolated from mining samples and those of the species description accordingly to Brenner et al. (2005).

\begin{tabular}{|c|c|c|c|c|}
\hline $\begin{array}{l}\text { Phenotypic } \\
\text { Trait }\end{array}$ & LAMA 1485 & LAMA 1486 & LAMA 1487 & A. cryptum \\
\hline Morphology & Rod & Rod & Rod & Rod \\
\hline Motility & - & - & - & + \\
\hline $\begin{array}{l}\text { Gram-colour } \\
\text { Anaerobic }\end{array}$ & - & - & - & - \\
\hline $\begin{array}{l}\text { growth } \\
\text { Cytochrome }\end{array}$ & - & - & - & - \\
\hline oxidase & - & - & + & - \\
\hline Catalase & + & + & + & + \\
\hline Acetate & - & + & - & - \\
\hline Lactate & - & + & - & - \\
\hline Lactose & - & - & - & + \\
\hline Succinate & - & - & - & - \\
\hline Maltose & - & + & - & + \\
\hline Sorbitol & - & + & - & + \\
\hline Methanol & - & + & - & - \\
\hline
\end{tabular}

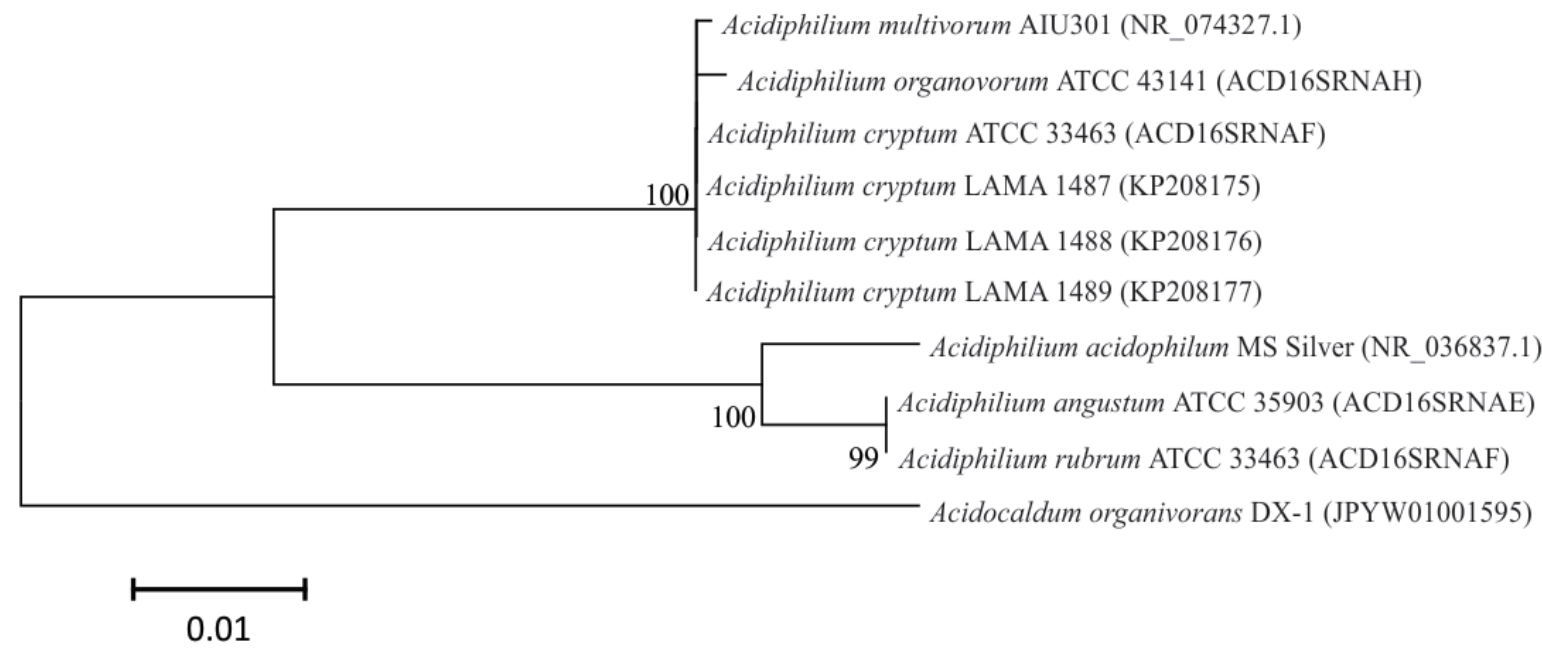

Figure 1 - Phylogenetic tree of the bacterial strains isolated in this work and related bacteria based on 165 rRNA gene sequences. The tree was reconstructed by the neighbor-joining method. The sequence of Acidicaldus organivorans DX-1 (JPYW01001595) was used as the outgroup to root the tree. Database access numbers are in parentheses following the organism names. Phylogeny was tested by the bootstrap method (percentages) based on 1000 replicates, shown in branching points. The model substitution was nucleotide type with the maximum likelihood method including transition + transversions using uniform rates of homogeneous groups with complete suppression for the gaps.

\section{Influence of $\mathrm{pH}$ on the Growth of Bacteria}

The results obtained from the $\mathrm{pH}$ experiments showed that all strains tested grew better at acidic $\mathrm{pH}$ (Figure 2), have statistical difference $(p=0,00002)$ and also possess normal distribution and homogeneity $(p=$ 0.050704 ). Thus, LAMA 1485 grew in the range of 2 to 4 , having statistically significant difference in $\mathrm{pH} 3$ and 4. LAMA 1486 and LAMA 1487 presented greater ranges of growth, in $\mathrm{pH}$ 2-5 and 3-6 respectively, with significant better growth at the $\mathrm{pH} 3$ for both strains.

\section{Influence of Metals on the Growth of Bacteria}

Growth of the three strains of $A$. cryptum was assessed in the presence of different metals and concentrations. According to statistical analysis, the copper metal showed the highest toxicity for all tested strains.

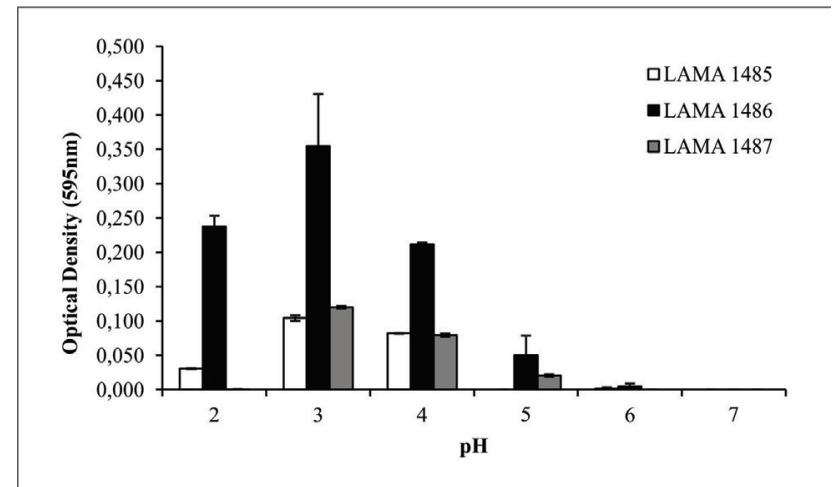

Figure 2 - Growth on different $\mathrm{pH}$ values, measure as optical density at $595 \mathrm{~nm}$, of the three bacterial strains isolated from acid samples. Vertical bars represent the standard deviation calculated from duplicate samples. 
LAMA 1485 grew significantly at the concentration of $1.0 \mathrm{mM}$ for the metal nickel, $0.1 \mathrm{mM}$ for copper and zinc metals $(p<0.000002)$. There was significant growth of LAMA 1486 at $1 \mathrm{mM}$ of nickel metal, zinc metal until $0.5 \mathrm{mM}$ and $0.1 \mathrm{mM}$ for copper metal $(p<0.000002)$. Already the LAMA 1487 strain grew significantly up to $0.5 \mathrm{mM}$ nickel metal and $0.1 \mathrm{mM}$ for the metals zinc and copper $(p=0.000000)$. The Bartlett test confirm the normal distribution and homogeneity, as shown by the values (LAMA $1485 p=0.079086$, LAMA $1486 p$ $=0.079086$ and LAMA $1487 p=0.674486)$ (Figure 3).

For all strains we could not properly measure the growth in the presence of selenium. During the experiments a red color developed in the culture media and was associated with a strong aggregation and precipitation of cells and metals. Nevertheless, when examined visually, it was observed that all three strains were able to growth on all concentrations tested of selenium.

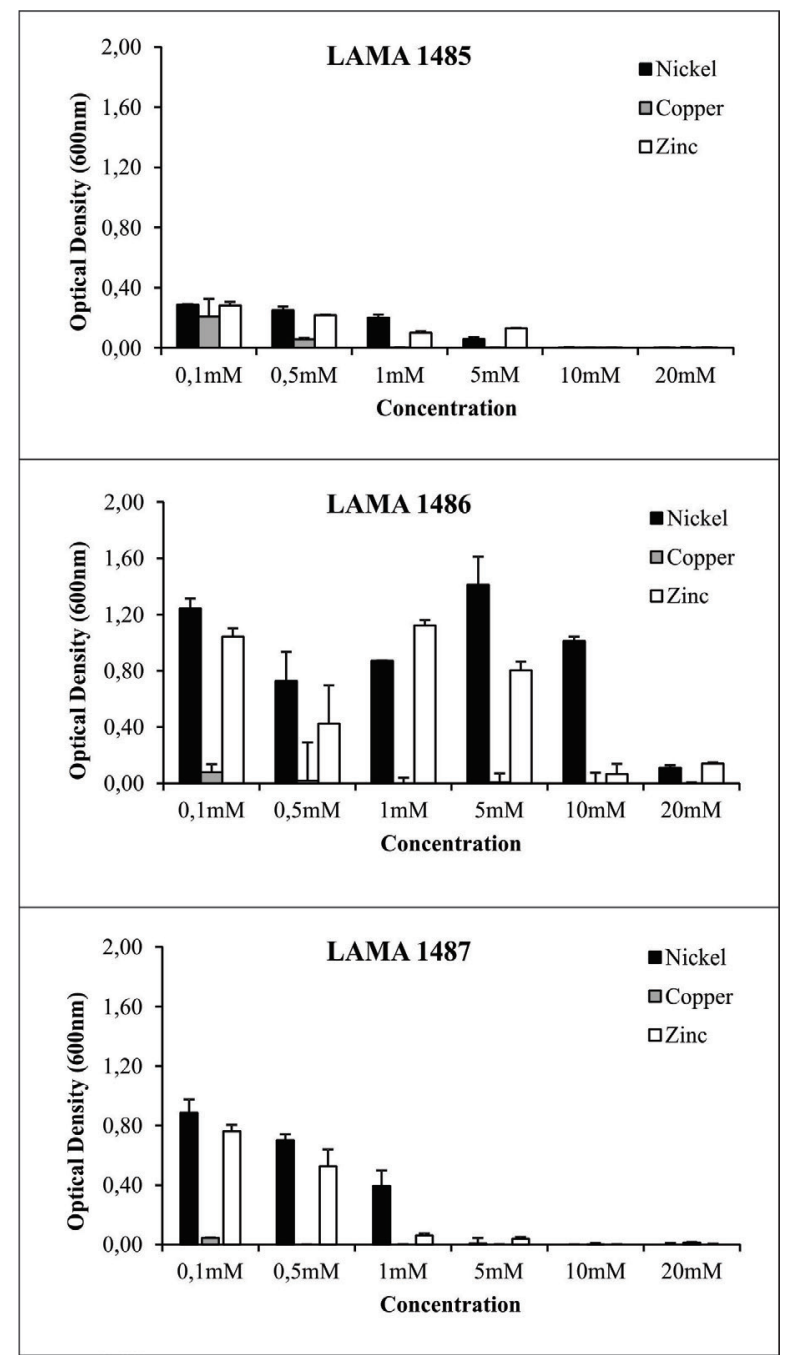

Figure 3 - Growth of the three bacterial strains isolated from acid samples on increasing concentrations of the metals nickel, copper, and zinc, measure as optical density at $600 \mathrm{~nm}$. Vertical bars represent the standard deviation calculated from duplicate samples.

\section{DISCUSSION}

The difficulty in cultivating acidophilic bacteria was already noted by Harrison (1984) who reported that these microorganisms are not easily grown, especially in solid medium, and they usually show slow growth rates, when compared to other bacteria. Besides, acidic environments are usually poor in dissolved carbon and bear micro zones where the oxygen concentration may vary. These features also contribute to make the isolation process more difficult (Johnson et al., 1993). The isolation of a small group of bacterial strains from acid environments was also reported by Kishimoto et al. (1993) and Dore et al. (2003), although this may vary accordingly to the culture media employed (Kishimoto \& Tano 1987).

All the three strains resemble microorganisms from the acidophilic genera Acidiphilium and Acidocella in their morphology and enzymatic activities. The strains LAMA 1485 and LAMA 1487 are phenotypically more similar to Acidiphilium, considering that bacteria belonging to this genus are unable to growth in the presence of acetate, lactate and succinate (Hiraishi \& Imhoff, 2005). LAMA 1486 is more similar to Acidocella in it ability to growth in the presence of acetate and lactate, and in being nutritionally more versatile (Hiraishi, 2005).

As reported by Yang et al. (2007) and Auld et al. (2013) the genus Acidiphilium is one of the dominants in acid mine drainage, and has been detected by both culture-dependent and independent methods. The species $A$. cryptum has been frequently cultivated from mining environments, being reported from a coal mine lake in Germany (Küsel et al., 1999), in a Norwegian cooper mine (Johnson et al., 2001) and from AMD from Chinese lead and zinc tailings (Tan et al., 2007), for instance. Thus our report of $A$. cryptum in some of the mining environments of South Brazil, although for the first time, is in agreement with the dominance and cosmopolitan occurrence of these bacteria.

Despite of the close phylogenetic relationship to $A$. cryptum, as based on $16 \mathrm{~S}$ gene sequences, our strains differed in a few characteristics from this species. Unlike the description given by Hiraiashi \& Imhoff (2005), strains LAMA 1485 and 1487 were unable to assimilate lactose, maltose and sorbitol, and LAMA 1486 were unable to assimilate lactose but did grew on acetate, lactate and methanol. Although $16 \mathrm{~S}$ gene sequences are the most routinely used method of identification of bacteria, it is not always reliably to differentiate at the species level (Logan \& Halket, 2011). Some bacteria, like the members of the Bacillus cereus group, have almost identical 16S gene sequences, being differentiated by its physiological and virulence characteristics (Jung et al., 2011). On the 
other side, an emerging concept in microbial taxonomy is the ecotype concept, which states that within a species there are different subgroups that have adapted to their environment in different ways using, for instance, different carbon sources (Barton \& Northup, 2011). These ecotypes may occur in the same environment since on a microbial scale it may be heterogeneous regarding the types and concentrations of different carbon sources (Vos et al., 2013), favoring coexistence without overlapping niches, as reported previously in epiphytic bacteria (Wilson \& Lindow, 1994). So, it is possible that our strains belong to different ecotypes of $A$. cryptum, or even belong to new species. Whole genome DNA-DNA hybridization (Barton \& Northup, 2011; Logan \& Halket, 2011) may be used to establish the final identity of these strains.

These results confirm the acidophilic nature of the three isolated strains and are in agreement with the $\mathrm{pH}$ optimum and range for growth reported in other taxonomic related strains. Harrison (1981) in the original description of the species reported growth between pH 1.9 and 5.9, while Peng et al. (2008) reported the $\mathrm{pH}$ range for growth of 1.5 and 5.0, with optimum at 3.5 for a strain of Acidiphilium with $99 \%$ of similarity with $A$. cryptum. Küsel et al. (1999) reported that $A$. cryptum strain JF-5 grew between $\mathrm{pH} 2.1$ and 5.8, with optimum at 3.2 and Zhang et al. (2013) reported the $\mathrm{pH}$ range for growth of 1.0 and 6.0 , with optimum at 3.5, for another strain closely related to A. cryptum.

The tolerance to high concentrations of toxic metals is a characteristic of the genus Acidiphilium, but is variable among strains, as observed in this work. Accordingly, Dopson et al. (2003) reported previously that strains of the genus Acidiphilium tolerate between 10 and $350 \mathrm{mM}$ of nickel, although the mechanisms of resistance were unknown. Acidiphilium cryptum were showed to tolerate up to $20 \mathrm{mM}$ of this metal (Mahapatra \& Banerjee, 1996). More recently, MartinUriz et al. (2014) studied the mechanisms of nickel tolerance in the strain Acidiphilium sp. PM by a genomic approach. This organism could grow in concentrations of $1 \mathrm{M}$ of $\mathrm{Ni}$, but required a lag phase of ten days to do that. Besides, most of the cells of the population were sensitive to nickel concentrations higher than $20 \mathrm{mM}$. In the present study, the experiments of metal tolerance involved an incubation period of seven days, so again it can be said that the tolerance of our strains are in agreement with the general tolerance of the genus Acidiphilium and the species $A$. cryptum in particular. The mechanisms of nickel tolerance, as determined by Martin-Uriz et al. (2014), may involve intra and extra cellular accumulation, associated with the presence of at least seven genes. Intracellular accumulation of nickel, iron and chromium was previously reported for Acidiphilium rubrum (Itoh et al., 1998).
Among the four metals studied, copper was the most toxic to our strains. Although Dopson et al. (2003) reported that maximum tolerance of the genus Acidiphilium to copper varies between 5 to $15 \mathrm{mM}$, higher values than observed in the present study, theses values are lower than those reported for other metals, which is in agreement with our results. Several strategies may be used by microorganisms to deal with the occasional or frequent exposition to metals and other toxic substances (Nies, 2003; Baker-Austin \& Dopson, 2007). These include changes in cell morphology (Young, 2006) which was reported by Chakravart \& Banerjee (2008) for $A$. symbioticum H8. For specific metals, these microorganisms may employ different resistance mechanisms. Gram-negative bacteria may resist to toxic levels of copper by accumulating it in the periplasm, preventing it of reaching the cell interior. Because of this mechanism colonies develop a blue color (Richards et al., 2002), which was not observed in our strains and was reported only in non-acidophilic bacteria. As reported for other acidophilic genera (Acidithiobacillus, for instance), our strains may be employing an efflux system to tolerate high concentrations of copper or/and the enzyme multicopper oxidase to reduce toxic $\mathrm{Cu}^{+}$to the less toxic state $\mathrm{Cu}^{2+}$ (Wen et al., 2014). Another resistance mechanism may involve the internal sequestering of copper in polyphosphate granules, as reported for Acidithiobacillus ferrooxidans (Dopson \& Holmes, 2014).

As for the other metals, the level of tolerance to zinc was variable among the strains studied. Resistance to zinc is accomplished by the efflux of the metal through ATPases or other membrane transport systems (Dopson \& Holmes, 2014) and seems to be mediated by plasmids, at least in A. symbioticum KM2 (Mahapatra et al., 2002). The tolerance of different Acidiphilium strains is usually higher than those observed in our strains, between 8 and $150 \mathrm{mM}$ (Dopson et al., 2003), with the exception of LAMA 1486 which was able to grow in all concentrations tested (up to $20 \mathrm{mM}$ ).

Resistance to selenium, to our knowledge, was not previously studied in the genus Acidiphilium. Our strains seem to be employing a mechanism of reduction to tolerate the presence of selenium, considering the red color developed during the incubation period. This red color is elemental selenium, which is a less toxic form (Richards et al., 2002). Selenium is a nutrient to bacteria and in toxic concentrations is accumulated externally (Richards et al., 2002) but some organisms may deposit nanospheres of this element in the cytosol through respiratory metabolism. This phenomenon was reported in Bacillus selenitireducens, Sulfurospirillum barnesii and Selenihalanaerobacter shriftii (Langley, 2006), but not in the genus Acidiphilium. Accordingly, 
our observations suggest that it is precipitated after reduction, but further investigation is needed to confirm the specific local of accumulation.

The three Acidiphilium strains studied differed in the ability to tolerate the metals tested. LAMA 1486 was more tolerant to zinc and nickel, while LAMA 1485 exhibited a higher tolerance to copper. This variability may be associated to differences in the expression of genes coding for resistance traits, due to the presence of strong or weak promoters, for instance (Sanchez et al., 2011). Dopson \& Holmes (2014) also suggested that different levels of tolerance may be related to the presence of multiple mechanisms of resistance or associated with gene duplications.

\section{ACKNOWLEDGMENTS}

The authors would like to thank FAPESC (Fundação de Amparo à Pesquisa de Santa Catarina - Research Support Foundation of Santa Catarina) for the study grant and UNIVALI (Universidade do Vale do Itajaí - University of Vale do Itajaí) for material and financial support.

\section{REFERENCES}

Auld, R.R.; Myre, M.; Mykytczuk, N.C.S.; Leduc, L.G. \& Merritt, T.J.S. 2013. Characterization of the microbial acid mine drainage microbial community using culturing and direct sequencing techniques. J. Microbiol. Meth. 93: 108-115.

Baker-Austin. C. \& Dopson, M. 2007. Life in acid: $\mathrm{pH}$ homeostasis in acidophiles. Trends Microbiol. 15: 165-171.

Barton, L.L. \& Northup, D.E. 2011. Microbial ecology: beginnings and the road forward. In: Microbial Ecology. Wiley-Blackwell, New Jersey, 1-28pp.

Bilgin, A.A.; Silverstein, J.A. \& Jenkins, J.D. 2004. Iron respiration by Acidiphilium cryptum at $\mathrm{pH}$ 5. FEMS Microbiol Ecol. 49: 137-143.

Brenner, D.J; Krieg, N.R.; Staley, J.T. Bergey's Manual of Systematic Bacteriology, $2^{\mathrm{a}}$ ed. New York: Springer Science, 2005.

Chakravarty, R. \& Banerjee, P.C. 2008. Morphological changes in an acidophilic bacterium induced by heavy metals. Extremophiles 12: 279-284.

Crane, J.L. 2014. Source apportionment and distribution of polycyclic aromatic hydrocarbons, risk considerations, and management implications for urban stormwater pond sediments in Minnesota, USA. Arch. Environ. Contam. Toxicol. 66:176-200. Dopson, M.; Baker-Austin, C.; Koppineedi, P. R. \& Bond, P.L. 2003. Growth in sulfidic mineral environments: metal resistance mechanisms in acidophilic microorganisms. Microbiol. 149: 1959-1970.

Dopson, M. \& Holmes, D.S. 2014. Metal resistance in acidophilic microorganisms and its significance for biotechnologies. Appl. Microbiol. Biotechnol. 98: 8133-8144.

Dopson, M.; Ossandon, F.J.; Lövgren, L. \& Holmes, D. S. 2014. Metal resistance or tolerance? Acidophiles confront high metal loads via both abiotic and biotic mechanisms. Front. Microbiol. 5: 1-4.

Dore, S.Y.; Clancy, Q.E.; Rylee, S.M. \& Kulpa, C.F. 2003. Naphthalene-utilizing and mercury-resistant bacteria isolated from an acidic environment. Appl. Microbiol. Biotechnol. 63: 194-199.

Fischer, J.; Quentmeier, A.; Gansel, S.; Sabados, V. \& Friedrich, C.G. 2002. Inducible aluminum resistance of Acidiphilium cryptum and aluminum tolerance of other acidophilic bacteria. Arch. Microbiol. 178: 554-558.

Fuentes, S.; Méndez, V.; Aguila, P. \& Seeger, M. 2014. Bioremediation of petroleum hydrocarbons: catabolic genes, microbial communities, and applications. Appl. Microbiol. Biotechnol. 98: 4781-4794.

Garrity, G. M. 2004. Bergey's Manual of Systematic Bacteriology. Michigan: Springer.

Gemmell, R.T. \& Knowles, C.J. 2000. Utilisation of aliphatic compounds by acidophilic heterotrophic bacteria. The potential for bioremediation of acidic wastewaters contaminated with toxic organic compounds and heavy metals. FEMS Microbiol. Lett., 192: 185-190.

Hao, J.; Murphy, R.; Lim, E.; Schoonen, M.A.A. \& Strongin, D.R. 2009. Effects of phospholipid on pyrite oxidation in the presence of autotrophic and heterotrophic bacteria. Geochim. Cosmochim. Ac. 73: 4111-4123.

Harrison, A.P. 1984. The acidophilic thiobacilli and other acidophilic bacteria that share their habitat. Annu. Rev. Microbiol. 38: 265-295.

Harrison, A.P. 1981. Acidiphilium cryptum gen. nov., nov., heterotrophic bacterium from acidic mineral environments. Int. J. Syst. Bacteriol. 31(3): 327-332.

Hiraishi, A. \& Imhoff, J.F. 2005. Genus II. Acidiphilium Harrison 1981, 331VP emend. Kishimoto, Kosako, Wakao, Tano and Hiraishi 1995b, 90. In: Brenner, D.J.; Krieg, N.R. \& Staley, J.T. Bergey's Manual of Systematic Bacteriology Volume Two: The Proteobacteria Part C, The Alpha-, Beta-, Delta-, and Epsilonproteobacteria. 2th edition. Springer, New York, 54-62pp.

Hiraishi, A. 2005. Genus IV. Acidocella Kishimoto, Kosako, Wakao, Tano, and Hiraishi 1996, 362VP 
(Effective publication: Kishimoto, Kosako, Wakao, Tano, and Hiraishi 1995b, 90). In: Brenner, D.J.; Krieg, N.R. \& Staley, J.T. Bergey's Manual of Systematic Bacteriology Volume Two: The Proteobacteria Part C, The Alpha-, Beta-, Delta-, and Epsilonproteobacteria. 2th edition. Springer, New York, 65-68pp.

Itoh, S.; Iwak, N.; Wakao, N.; Yoshizu, K.; Aoki, A. \& Tazaki, K. 1998. Accumulation of $\mathrm{Fe}, \mathrm{Cr}$ and $\mathrm{Ni}$ metals inside cells of acidophilic bacterium Acidiphilium rubrum that produces $\mathrm{Zn}$-containing bacteriochlorophyll a. Plant Cell Physiol. 39(7): 740-744.

Ivanova, A.E.; Kizilova, A.K.; Kanat'eva, A.Y.; Kravchenko, I.K.; Kurganov, A.A. \& Belyaev, S. S. 2013. A hydrocarbon-oxidizing acidophilic thermotolerant bacterial association from sulfur blocks. Microbiol. 82(4): 482-489.

Jacques, R.J.S.; Bento, F.M.; Antoniolli, Z.I. \& Camargo, F.A.L. 2007. Biorremediação de solos contaminados com hidrocarbonetos aromáticos policíclicos. Ciência Rural, 37(4): 1192- 1201.

Johnson, D.B. \& Bridge, T.A.M. 2002. Reduction of ferric iron by acidophilic heterotrophic bacteria: evidence for constitutive and inducible enzyme systems in Acidiphilium spp. J. Appl. Microbiol. 92: 315-321.

Johnson, D.B.; Mcginness, S. \& Ghauri, M.A. 1993. Biogechemical cycling of iron and súlfur in leaching environments. FEMS Microbiol. Rev. 11: 63-70.

Johnson, D.B. 2012. Reductive dissolution of minerals and selective recovery of metals using acidophilic iron- and sulfate-reducing acidophiles. Hydrometallurgy, 127-128: 172-177.

Johnson, D.B. 1995. Selective solid media for isolating and enumerating acidophilic bacteria. J. Microbiol. Methods, 23: 205-218.

Johnson, D.B.; Rolfe, S.; Hallbergi, K.B. \& Iversen, E. 2001. Isolation and phylogenetic characterization of acidophilic microorganisms indigenous to acidic drainage waters at an abandoned Norwegian copper mine. Environ. Microbiol. 10: 630- 637.

Jones, R.M.; Hedrich, S. \& Johnson, D.B. 2013. Acidocella aromatica sp. nov.: an acidophilic heterotrophic alphaproteobacterium with unusual phenotypic traits. Extremophiles, 17: 841-850.

Jung, M.Y.; Kim, J.S.; Paek, W.K.; Lim, J.; Lee, H.; Kim, P.I.; Ma, J.Y.; Kim, W. \& Chang, Y.H. 2011. Bacillus manliponensis sp. nov., a new member of the Bacillus cereus group isolated from foreshore tidal flat sediment. J. Microbiol. 49(6): 1027-1032.

Kang, J.W. 2014. Removing environmental organic pollutants with bioremediation and phytoremediation. Biotechnol. Lett. 36: 1129-1139.
Kishimoto, N.; Kosako, Y. \& Tano, T. 1993. Acidiphilium aminolytica sp. nov.: an acidophilic chemoorganothrophic bacterium isolated from acidic mineral environment. Curr. Microbiol. 27: 131-136.

Kishimoto, N. \& Tano, T. 1987. Acidophilic heterotrophic bacteria isolated from acid mine drainage, sewage, and soils. Appl. Microbiol. 33: 11-25.

Küsel, K.; Dorsch, T.; Acker, G. \& Stackebrandt, E. 1999. Microbial reduction of $\mathrm{Fe}(\mathrm{III})$ in acidic sediments: isolation of Acidiphilium cryptum JF-5 capable of coupling the reduction of Fe(III) to the oxidation of glucose. Appl. Environ. Microbiol. 65(8): 3633-3640.

Langley, S. 2006. Metal inclusions in bacteria. In.: Steinbüchel, S. \& Shively, J.M. Microbiology Monographs: Inclusions in Prokaryotes. SpringerVerlag, Berlin, 314-321pp.

Logan. N.A. \& Halket, G. 2011. Developments in the taxonomy of aerobic, endospore-forming bacteria; In: Logan NA, Vos PD. Endospore-forming soil bacteria. Springer, New York, 1-29pp.

Mahapatra, N.R. \& Banerjee, P.C. 1996. Extreme tolerance to cadmium and high resistance to copper, nickel and zinc in different Acidiphilium strains. Lett, Appl, Microbiol, 23: 393-397.

Mahapatra, N.R.; Ghosh, S.; Deb, C. \& Banerjee, P.C. 2002. Resistance to cadmium and zinc in Acidiphilium symbioticum KM2 is plasmid mediated. Curr. Microbiol. 45: 180-186.

Martin-Uriz, P.S.; Mirete, S.; Alcolea, P.J.; Gomez, M.J.; Amils, R. \& Gonzalez-Pastor, J.E. 2014. Nickelresistance determinants in Acidiphilium sp. PM identified by genome-wide functional screening. PLoS ONE. 9(4): e95041.

Meyer, W.; Seiler, T.B.; Schwarzbauer, J.; Püttmann, W.; Hollert, H. \& Achten, C. 2014. Polar polycyclic aromatic compounds from different coal types show varying mutagenic potential, EROD induction and bioavailability depending on coal rank. Sci. Total. Environ. 494-495: 320-328.

Nicomrati, D.; Dick, W.A. \& Tuovinenl, O.H. 2006. Assessment of the microbial community in a constructed wetland that receives acid coal mine drainage. Microb. Ecol. 51(1): 83-89.

Nies, D.H. 2003. Efflux-mediated heavy metal resistance in prokaryotes. FEMS Microbiol. Rev. 27: 313-339.

Peng, J.; Zhang, R.; Zhang, Q.; Zhang, L. \& Zhou, H. 2008. Screening and characterization of Acidiphilium sp. PJH and its role in bioleaching. Trans. Nonferrous Met. Soc. China 18: 1443-1449. Richards, J.W.; Krumholz, G.D.; Chval, M.S. \& Tisa, L.S. 2002. Heavy metal resistance patterns of 
Frankia strains. Appl. Environ. Microbiol. 68(2): 923-927.

Sanchez, A.; Garcia, H.G.; Jones, D.; Phillips, R. \& Kondev, J. 2011. Effect of promoter architecture on the cell-to-cell variability in gene expression. PLoS Comput. Biol. 7(3): e1001100.

Stackebrandt. E. \& Ebers, J. 2006. Taxonomic parameters revisited: tarnished gold standards. Microbiol. Today 33: 152-155.

Stapleton, R.D.; Savage, D.C.; Sayler, G.S. \& Stacey, G. 1998. Biodegradation of aromatic hydrocarbons in an extremely acidic environment. Appl. Environ. Microbiol. 64(11): 4180-4184.

Tamura, K.; Peterson, D.; Peterson, N.; Stecher, G.; Nei, M. \& Kumar, S. 2011. MEGA5: molecular evolutionary genetics analysis using maximum likelihood, evolutionary distance, and maximum parsimony. Method. Molecul. Biol. Evol. 28: 2731-2739.

Tan, G.; Shu, W.; Hallberg, K.B.; Li, F.; Lan, C. \& Huang, L. 2007. Cultivation-dependent and cultivationindependent characterization of the microbial community in acid mine drainage associated with acidic $\mathrm{Pb} / \mathrm{Zn}$ mine tailings at Lechang, Guangdong, China. FEMS Microbiol. Ecol. 59: 118-126.

Vos, M.; Wolf, A.B.; Jennings, S. J.; \& Kowalchuk, G. A. 2013. Micro-scale determinants of bacterial diversity in soil. FEMS Microbiol. Rev. 37: 936-954.

Watling, H.R.; Collinson, D.M.; Li, J.; Mutch, L.A.; Perrot, F.A. \& Rea, S.M. 2014. Bioleaching of a low-grade copper ore, linking leach chemistry and microbiology. Miner. Eng. 56: 35-44.

Wen, Q.; Liu, X.; Wang, H. \& Lin, J. 2014. A versatile and efficient markerless gene disruption system for Acidithiobacillus thiooxidans: application for characterizing a copper tolerance related multicopper oxidase gene. Environ. Microbiol. doi:10.1111/1462-2920.12494.

Wilson, M. \& Lindow, S. E. 1994. Coexistence among epiphytic bacterial populations mediated through nutritional resource partitioning. Applied and Environmental Microbiology 60(12): 4468-4477.

Xu, A.; Xia, J.; Song, Z.; Jiang, P.; Xia, Y. \& Wan, M. 2013. The effect of energy substrates on PHB accumulation of Acidiphilium cryptum DX1-1. Curr. Microbiol. 67: 379-387.

Yang, Y.; Wan, M.; Shi, W.; Peng, H.; Qiu, G.; Zhou, J. \& Liu, X. 2007. Bacterial diversity and community structure in acid mine drainage from Dabaoshan Mine, China. Aquat. Microb. Ecol. 47: 141-151.

Young, K.D. 2006. The selective value of bacterial shape. Microbiol. Mol. Biol. Rev. 70(3): 660-703.

Zhang, Y.; Peng, A.; Yang, Y.; Liu, J. \& Qiu, G. 2013. Isolation, characterization of Acidiphilium sp. DX1-1 and ore bioleaching by this acidophilic mixotrophic organism. Trans. Nonferrous Met. Soc. China 23: 1774-1782.

Submetido: Julho/2015

Revisado: Novembro/2016

Aceito: Janeiro/2017 